\title{
Molecular Level Factors Affecting the Efficiency of Organic Chromophores for $p$-Type Dye Sensitized Solar Cells
}

\author{
Svitlana Karamshuk ${ }^{1}$, Stefano Caramori ${ }^{2, *}$, Norberto Manfredi ${ }^{1}$, Matteo Salamone ${ }^{1}$, \\ Riccardo Ruffo ${ }^{1}$, Stefano Carli ${ }^{2}$, Carlo A. Bignozzi ${ }^{2}$ and Alessandro Abbotto ${ }^{1, *}$ \\ Received: 5 October 2015; Accepted: 24 December 2015; Published: 7 January 2016 \\ Academic Editor: Claudia Barolo \\ 1 Department of Materials Science and Milano-Bicocca Solar Energy Research Center-MIB-Solar, \\ University of Milano-Bicocca, INSTM Unit, Via Cozzi 55, 20125 Milano, Italy; svitlpetrova@gmail.com (S.K.); \\ norberto.manfredi@unimib.it (N.M.); matteo.salamone@unimib.it (M.S.); riccardo.ruffo@unimib.it (R.R.) \\ 2 Department of Chemistry, University of Ferrara, Via L. Borsari 46, 44121 Ferrara, Italy; \\ stefano.carli@unife.it (S.C.); carloalberto.bignozzi@unife.it (C.A.B.) \\ * Correspondence: stefano.caramori@unife.it (S.C.); alessandro.abbotto@unimib.it (A.A.)
}

\begin{abstract}
A series of mono- and di-branched donor- $\pi$-acceptor charge-separated dyes incorporating triphenylamine as a donor and either Dalton's or benzothiadiazole group as strong acceptors was synthesized and its fundamental properties relevant to the sensitization of nanocrystalline $\mathrm{NiO}$ investigated. The dyes exhibited an intense visible absorption band with a strong charge transfer character favorable to $\mathrm{NiO}$ sensitization, shifting the electron density from the donor to the acceptor branches. Nevertheless, the computed exciton binding energy is circa twice that of a common literature standard (P1), suggesting a more difficult charge separation. When tested in $p$-type dye-sensitized solar cells the dyes successfully sensitized $\mathrm{NiO}$ electrodes, with photocurrent densities about half than that of the reference compound. Being recombination kinetics comparable, the larger photocurrent generated by P1 agrees with the superior charge separation capability originating by its smaller exciton binding energy.
\end{abstract}

Keywords: dyes; heteroaromatic; visible absorption; dipolar; donor-acceptor; triphenylamine; branched; Suzuki coupling; DFT-TDDFT

\section{Introduction}

With the increasing demand of clean, secure, cost-effective, and renewable energy sources, the exploitation of solar light as a major source has clearly emerged as a key strategic priority. Following the first publication of Grätzel and O'Regan in 1991 [1], dye-sensitized solar cells (DSSCs) were recognized as a relatively cheap and easy-to-scale approach to direct solar-to-electrical power conversion. Furthermore, their transparency, versatile design and wide color palette offer unique structural and architectural possibilities in the emerging field of building integration [2,3], for example through the realization of photovoltaic windows and façades. The key feature of DSSCs is the sensitization of a porous wide-band-gap semiconductor thin film with a photoactive dye, which, following excitation, is able to transfer either electrons ( $n$-type sensitization) or holes ( $p$-type sensitization) to a semiconductor substrate. $n$-type DSSCs have been intensively investigated over the last two decades, recently reaching optimized power conversion efficiencies up to $13 \%$ with a single photoactive junction (dye $/ n-\mathrm{TiO}_{2}$ ) [4]. Despite this recent progress, power conversion efficiencies in $n$-type DSSCs seem to have reached a plateau, urging the search for new viable approaches to further increase DSSCs efficiencies. A particularly promising strategy to produce DSSCs with significantly 
enhanced power conversion efficiencies is the connection of an $n$-type photoelectrode $\left(n\right.$-dye $\left./ \mathrm{TiO}_{2}\right)$ with a $p$-type photoelectrode ( $p$-dye/NiO), affording a tandem cell composed by two serially connected photoactive electrodes, each contributing to the total photovoltage delivered by the cell. Applying such a concept, organic-based photovoltaic devices with up to $40 \%$ conversion efficiency could be theoretically achievable [5]. Unfortunately, thus far, sensitized $p$-type systems have been much less investigated and much lower photocurrents, compared to their $n$-type counterparts, have been reported [6]. One of the main limitations in $p$-type systems, commonly based on $\mathrm{NiO}$ as a hole semiconductor [7], arises from the fast charge recombination [8] between the photoinjected hole in $\mathrm{NiO}$ and the reduced dye. Therefore, it is essential to develop new $p$-type chromophores, which could produce a long-lived charge separated state and minimize back recombination.

Several families of $p$-type dyes have been so far synthesized for this purpose. Those based on coumarin, porphyrin and peryleneimide scaffolds showed incident monochromatic photon-to-current conversion efficiencies (IPCE) only up to $4 \%$ and overall efficiencies lower than $0.2 \%$ [9-12]. One of the best examples of improved charge separation through dye design is represented by push-pull systems based on a di-branched $\mathrm{D}-(\pi-\mathrm{A})_{2}$ (where $\mathrm{D}=$ electron-donor group, $\pi=\pi$-spacer, and $\mathrm{A}=$ electron-acceptor group) structures, like P1, firstly reported in 2008 by Sun and coworkers [13]. This prototypical $p$-type dye had a carboxylic anchoring group on the triphenylamine donor moiety bridged to a dicyanovinyl acceptor by a thienylene ring acting as a $\pi$-linker. The di-branched architecture, constituted by one donor and two $\pi$-spacer and acceptor units, follows the same design strategy used for recent $n$-type DSSC sensitizers [14-16]. Using the same general and successful principles, more complex dyes based on much more elaborate triphenylamine/oligothiophene dyes have soon followed [17-22]. Nevertheless, even in the best cases, the power conversion efficiencies obtained by $p$-type sensitizers are still about one order of magnitude lower than then the average efficiency delivered by $n$-type devices.

We were thus triggered to explore new structures for potentially efficient chromophores for $p$-type devices, by considering that the intramolecular charge transfer, at the basis of efficient charge separation in donor-acceptor dyes, is strongly dependent on the electron-withdrawing ability of the acceptor. We have therefore designed and investigated new $p$-type dyes where P1-like structures have been optimized by inserting stronger and more efficient electron-acceptor groups compared to the conventional dicyanovinyl moiety. First, we have designed the SK2 dye, where the dicyanovinyl group of $\mathbf{P 1}$ has been replaced by the much stronger 3-cyano-2-(dicyanomethylene)-4,5,5-trimethyl-2,5-dihydrofuran (Dalton's acceptor) group, widely used in other materials science fields [23]. Second, mono- and di-branched dyes (SK3 and SK4), characterized by a D- $\pi-\mathrm{A}-\pi$ architecture, were realized. In the latter dyes, an additional benzothiadiazole-based acceptor-spacer unit was introduced both in linear (SK3) and branched (SK4) geometrical motifs for the manifold purpose of increasing the transition dipole moment, improving the spatial separation between hole and electron, and favoring the electron transfer to the electron mediator $\left(\mathrm{I}^{-} / \mathrm{I}_{3}{ }^{-}\right)$, resulting in improved interfacial charge separation.

Herein, we report the synthesis of the new $p$-type chromophores as well as their computational, electrochemical and photoelectrochemical properties in comparison with the literature standard P1. We have investigated the new dyes (Figure 1) as $p$-type sensitizers in $p$-type DSSC and the results were compared with the reference dye $\mathbf{P 1}$. 
<smiles>N#CC(C#N)=Cc1ccc(-c2ccc(N(c3ccc(C(=O)O)cc3)c3ccc(-c4ccc(C=C(C#N)C#N)s4)cc3)cc2)s1</smiles>

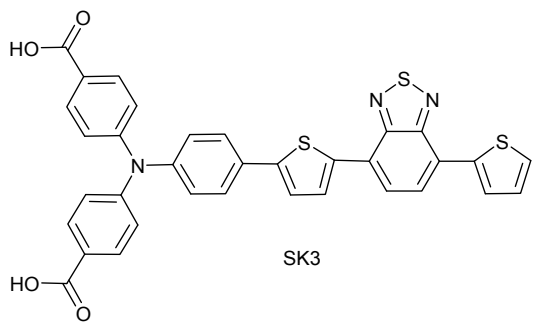

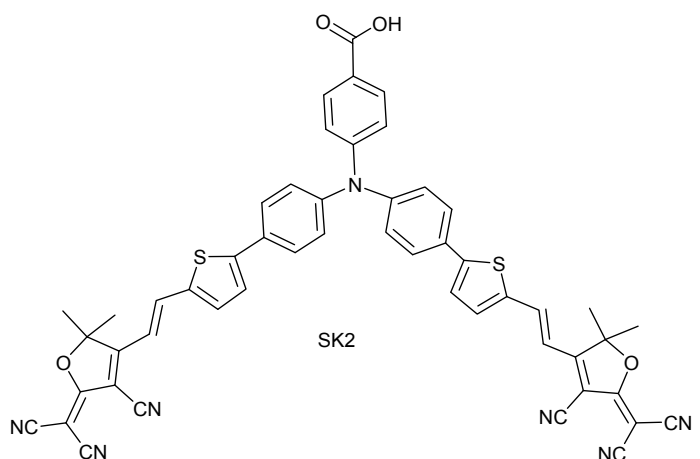

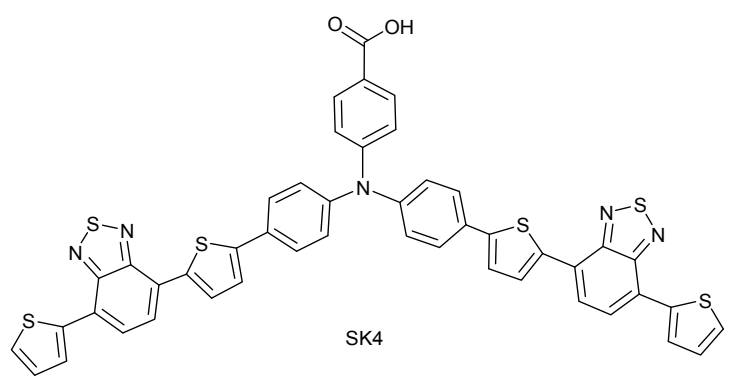

Figure 1. Structure of the investigated and reference (P1) dyes.

\section{Results and Discussion}

\subsection{Synthesis}

SK2, SK3 and SK4 were obtained following a synthetic pathway shown in Scheme 1. 4-[Bis-(4-bromophenyl)amino]benzaldehyde (1) was oxidized to the corresponding benzoic acid 2 by standard silver mirror reaction and then submitted to the Suzuki coupling with 5-formyl-2-thienylboronic acid for introducing the two thienyl linkers [13]. Knoevenagel reaction between the resulting bis-aldehyde 3 and 2-(3-cyano-4,5,5-trimethylfuran-2(5H)-ylidene)malononitrile afforded the desired chromophore SK2. It should be noted that the Knoevenagel condensation of 3 could be successfully accomplished only in acidic conditions at relatively high temperatures $\left(>75^{\circ} \mathrm{C}\right)$, while the reaction under conventional basic conditions (piperidine/EtOH) did not afford the condensation product, likely for the presence of the terminal $\mathrm{COOH}$ substituent on the donor core.

Preparation of SK3 and SK4 started from bromination of 4,7-di(thiophen-2-yl)benzo[c][1,2,5] thiadiazole (4) to the mono-bromide 5 using $N$-bromosuccinimide (NBS) in presence of a 1:1 solution of $\mathrm{CH}_{2} \mathrm{Cl}_{2}$ and acetic acid [24]. Since such reaction gave mono- and di-substituted products possessing close polarities, the separation of these two compounds by column chromatography had to be performed with care in order to afford the mono-derivative in moderate yields. Borination of 5 with bis(pinacolato)diboron resulted in the key intermediate boronic ester 6 . Different reaction conditions (solvent, base, and temperature) were investigated for Suzuki condensation between 6 and triphenylamine derivatives. The best choice in both cases was dimethoxyethane (DME) as a solvent and aqueous solution of $\mathrm{K}_{2} \mathrm{CO}_{3}$ as a base. Under these conditions, the coupling reaction started immediately after mixing up the reagents and within a considerably short time afforded the desired targets $\mathbf{7}$ and $\mathbf{8}$ with fairly good yields. SK3 and SK4 were then obtained by following the previously described procedure for SK2. 


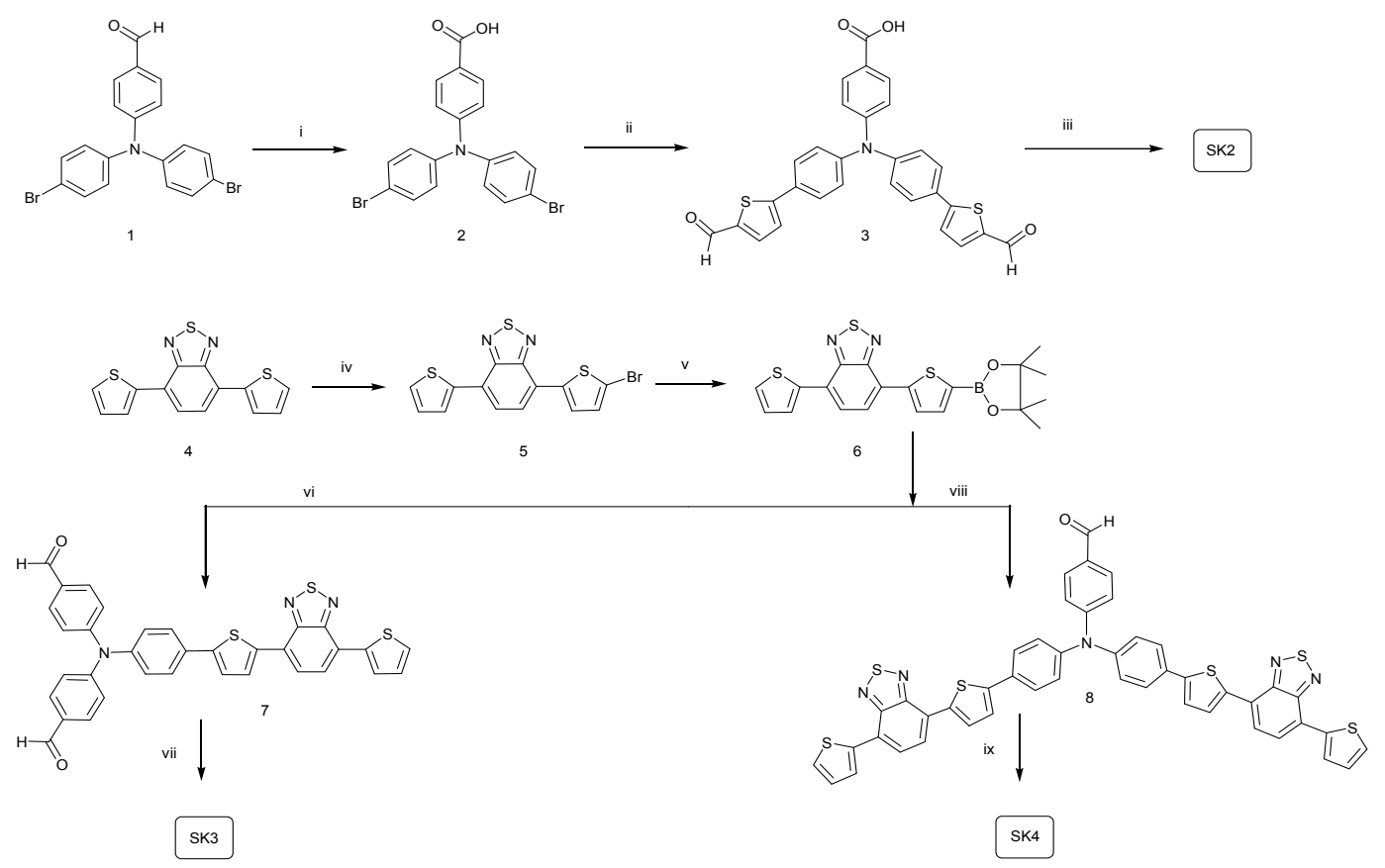

Scheme 1. Synthesis of SK2, SK3 and SK4. Reagents and conditions: (i) $\mathrm{Ag}_{2} \mathrm{O}, \mathrm{EtOH}$, $\mathrm{NaOH}$, r.t.; (ii) $\mathrm{Pd}$ (dppf) $\mathrm{Cl}_{2}$, 5-formyl-2-thienylboronic acid, $\mathrm{K}_{2} \mathrm{CO}_{3}$, toluene/ $\mathrm{MeOH}$, microwave; (iii) 2-(3-cyano-4,5,5-trimethylfuran-2(5H)-ylidene)malononitrile, $\mathrm{NH}_{4} \mathrm{OAc} / \mathrm{AcOH}$, EtOH, reflux; (iv) NBS, $\mathrm{CH}_{2} \mathrm{Cl}_{2} / \mathrm{AcOH}$, r.t.; (v) bis(pinacolato)diboron, $\mathrm{Pd}(\mathrm{dppf}) \mathrm{Cl}_{2}, \mathrm{KOAc}$, dioxane, reflux; (vi) 4-bromo- $N, N$-bis(4-formylphenyl)aniline, $\mathrm{Pd}(\mathrm{dppf}) \mathrm{Cl}_{2}$, aq. $\mathrm{K}_{2} \mathrm{CO}_{3}, \mathrm{DME}$, reflux; (vii) $\mathrm{Ag}_{2} \mathrm{O}$, $\mathrm{EtOH}, \mathrm{NaOH}$, r.t.; (viii) 4-(bis(4-bromophenyl)amino)benzaldehyde, $\mathrm{Pd}$ (dppf) $\mathrm{Cl}_{2}$, aq. $\mathrm{K}_{2} \mathrm{CO}_{3}, \mathrm{DME}$, reflux; and (ix) $\mathrm{Ag}_{2} \mathrm{O}, \mathrm{EtOH}, \mathrm{NaOH}$, r.t.

\subsection{Spectroscopic and Electrochemical Properties}

The absorption spectra of SK2, SK3 and SK4 in dimethyl sulfoxide (DMSO) are depicted in Figure 2 together with that of the reference dye P1. The normalized absorption and emission spectra of the SK dye series are reported in Figure S1 (Supplementary Materials). All dyes under investigations exhibited similar general spectral features, summarized by two intense $\left(\varepsilon>3 \times 10^{4} \mathrm{M}^{-1} \cdot \mathrm{cm}^{-1}\right)$ relatively broad absorption bands extending the light harvesting up to $700 \mathrm{~nm}$ in the case of SK2, where the presence of an efficient intramolecular charge transfer to the strong electron-withdrawing groups resulted in a significant bathochromic shift $(c a .70 \mathrm{~nm})$ of the visible absorption maximum. SK3, SK4, and P1 are ca. $100 \mathrm{~nm}$ blue-shifted with respect to SK2, showing a visible absorption maximum at $480-490 \mathrm{~nm}$ and an absorption onset at $c a$. $600 \mathrm{~nm}$. In all cases, the second band is located in the UV region, with an absorption peak in the interval 350-370 nm, where SK3 and his di-branched analogue SK4, incorporating the same donor-acceptor side arm, showed the sharpest and most intense band. The main optical and electrochemical parameters together with HOMO/LUMO energies estimated by cyclic voltammetry in $0.1 \mathrm{M} \mathrm{TBAClO}_{4}$ in DMSO are collected in Table 1. 


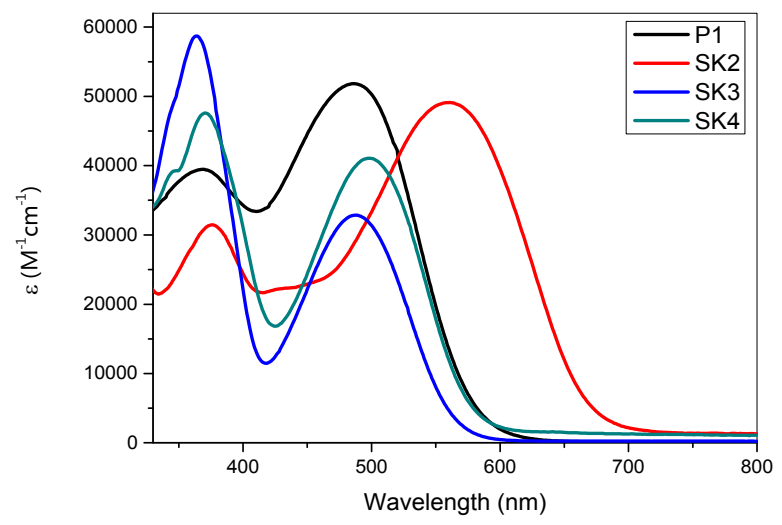

Figure 2. Absorption spectra of P1, SK2, SK3 and SK4 in dimethyl sulfoxide (DMSO).

Table 1. Optical and electrochemical parameters of the dyes. ${ }^{\text {a }}$

\begin{tabular}{|c|c|c|c|c|c|}
\hline Dye & $\begin{array}{c}\lambda_{\text {abs }}(\mathbf{n m})(\varepsilon) \\
\left(10^{4} \mathbf{M}^{-1} \cdot \mathbf{c m}^{-1}\right)\end{array}$ & $\begin{array}{l}\lambda_{\text {em }} \\
(\mathrm{nm})\end{array}$ & $\begin{array}{l}E^{\circ \circ} \\
(e V)^{b}\end{array}$ & $\begin{array}{l}\mathrm{E}_{(\mathrm{HOMO})} v s . \mathrm{NHE}(\mathrm{V}) \\
\left(v s . \text { Vacuum) }(\mathrm{eV})^{\mathrm{c}}\right.\end{array}$ & $\begin{array}{l}\mathrm{E}_{(\text {LUMO) }} \text { vs. NHE (V) } \\
\text { (vs. Vacuum) }(\mathrm{eV})^{\mathrm{c}}\end{array}$ \\
\hline P1 & $\begin{array}{l}372(3.97) ; \\
489(5.17)\end{array}$ & 611 & 2.14 & $1.34(-6.0)$ & $-0.62(-4.0)$ \\
\hline SK2 & $\begin{array}{l}373(3.12) \\
559(4.90)\end{array}$ & 674 & 1.91 & $1.26(-5.9)$ & $-0.22(-4.4)$ \\
\hline SK3 & $\begin{array}{l}357(5.87) \\
488(3.28)\end{array}$ & 609 & 2.21 & $1.17(-5.8)$ & $-0.85(-3.8)$ \\
\hline SK4 & $\begin{array}{l}365(4.76) ; \\
498(4.11)\end{array}$ & 621 & 2.17 & $1.16(-5.8)$ & $-0.86(-3.7)$ \\
\hline
\end{tabular}

${ }^{\mathrm{a}}$ in DMSO; ${ }^{\mathrm{b}}$ Calculated from the onset of the normalized absorption spectra of the dyes; ${ }^{\mathrm{c}}$ Evaluated from the DPV oxidation and reduction peak potentials in the presence of ferrocene as an internal reference $\left(\mathrm{E}_{1 / 2} \mathrm{Fc}^{+} / \mathrm{Fc}=0.68 \mathrm{~V}\right.$ vs. NHE) [25] and using a potential value of $-4.6 \mathrm{eV}$ for NHE $v s$. vacuum [26].

As often observed with organic D- $\pi$-A dyes $[27,28]$, the electrochemical behavior (Figure S2a, Supplementary Materials) of the series under investigation is dominated by irreversible processes that complicate a rigorous thermodynamic evaluation of the redox levels relevant to $\mathrm{NiO}$ sensitization. For these reasons, we have used the Differential Pulsed Voltammetry (DPV) to evaluate orbital energies. DPV shows higher sensitivity to Faradaic currents compared to other techniques (Figure S2b, Supplementary Materials). At anodic potentials, all chromophores presented a similar oxidation behavior resulting in an oxidation wave having a peak potential at $c a .0 .5 \mathrm{~V} v s$. $\mathrm{Fc}^{+/ 0}$, which is related to the oxidation of the electron-rich TPA group [29]. The reductive behavior is generally more complex, showing for all dyes a first, weak and irreversible wave likely originated by the reductive chemisorption of the acidic protons onto the electrode surface [30]. The following current wave corresponds to the injection of the electron into the LUMO orbital and was used to estimate the corresponding energy level. In agreement with the structural similarity of their acceptor group, SK3 and SK4 showed close LUMO energies at $-3.8 \mathrm{eV}$. This estimate is in reasonable agreement with the quasi-reversible wave observed at $-1.55 \mathrm{~V} v s . \mathrm{Fc}^{+/ 0}$. The reduction of SK2 dye, bearing a stronger acceptor group, is comparatively more anodically shifted with a lower energy LUMO at $-4.5 \mathrm{eV}$. Thus, no thermodynamic limitation to hole transfer to $\mathrm{NiO}$ are expected: in all cases, the HOMO energies are similar to the $\mathbf{P 1}$ dye and sufficiently lower than the upper valence band edge of $\mathrm{NiO}$, located at $0.5-0.6 \mathrm{~V}$ vs. NHE $[17,31]$. Electron transfer to $\mathrm{I}_{3}{ }^{-}$, relevant to dye regeneration, is in all cases, hexoergonic, with $\Delta \mathrm{G}^{\circ}$ values larger than $-0.2 \mathrm{eV}$, allowing to predict favorable kinetics.

\subsection{Computational Investigation}

To gain insights into the electronic and optical properties of the investigated sensitizers, we performed Density Functional Theory (DFT) calculations. All the calculations have been performed 
using the Gaussian 09 program package [32]. The dye structures at the ground state were optimized at the B3LYP level employing the 6-31G* basis set, starting from a semi-empirical PM3 pre-optimized geometry. Similar structural features were observed throughout the whole series. The nitrogen atom of the triphenylamine core gives rise to a distorted tetrahedral motif, resulting in a dihedral angle between the branches of the order of $40^{\circ}$. The $\pi$-A unit, constituted by thienylene bridges and dicyanovinly groups in P1 and SK2 and benzothiadiazole fragments in SK3 and SK4 (Figure 3), is essentially planar in agreement with the presence of an extended $\pi$-electron delocalization. Each branch is linked to the electron donating group via a benzene ring, with a dihedral angle of about $20^{\circ}-27^{\circ}$. Such twisting angle is expected to be beneficial for decoupling holes and electrons, once the initial charge separation is achieved.
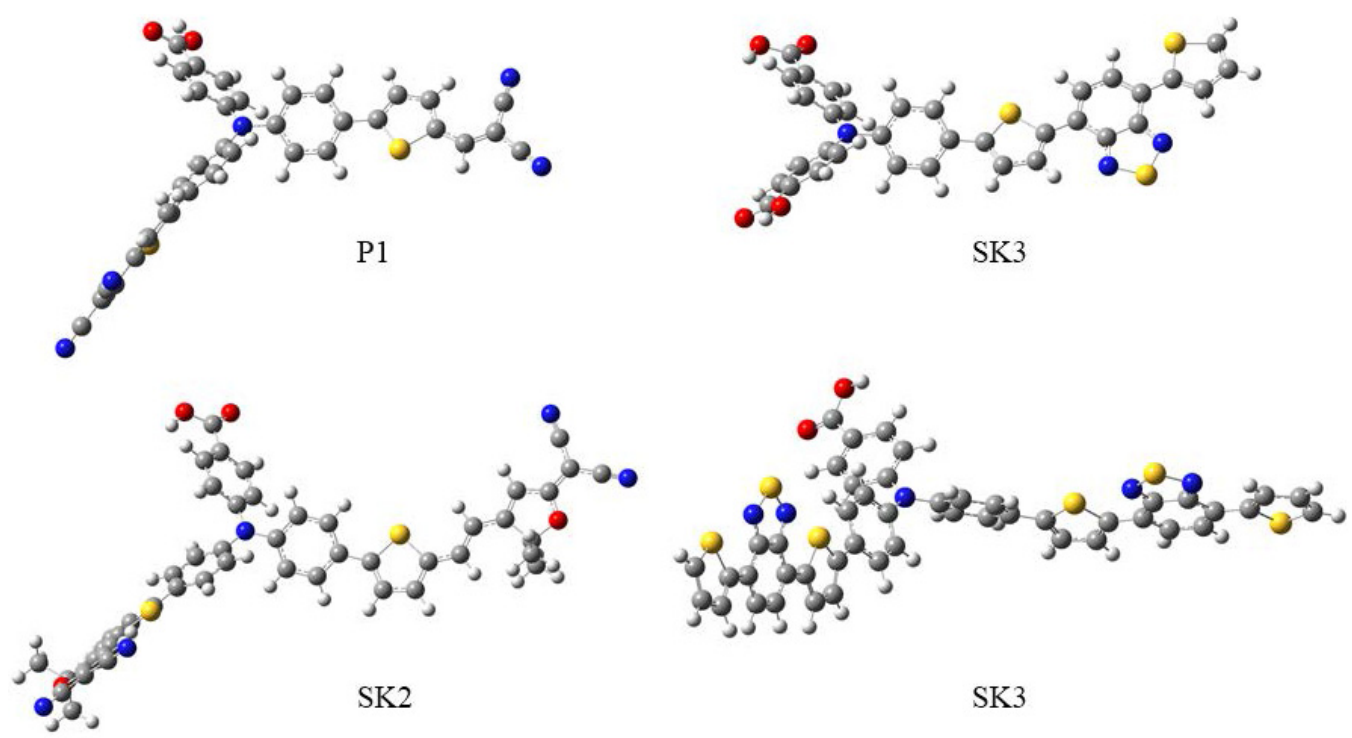

Figure 3. Equilibrium geometries of the $p$-type dyes under investigation calculated at the DFTB3LYP6-31G* level.

It is notoriously difficult for Time-Dependent DFT (TDDFT) methods to reliably describe charge transfer states, particularly those involving spatially separated orbitals and long range excitations as in the case of our $p$-type systems $[33,34]$. Therefore, in the attempt to drive reasonable insights on the electronic structure and excited state energetics of the dye series under investigation, the excitation energies (Table 2), resulting from calculations with B3LYP [35] and BH \& H (Half and Half) [36,37] functionals were compared. Frontier orbitals isodensity maps (isovalue of 0.02 ) of the selected dyes are depicted in Figure S3 (Supplementary Materials).

Table 2. Comparison of experimental and calculated lowest absorption maximum of the investigated dyes in DMSO.

\begin{tabular}{|c|c|c|c|c|c|}
\hline Dye & $\begin{array}{c}E_{\exp }(e V) \\
{\left[\lambda_{\max }(\mathbf{n m})\right]}\end{array}$ & $\begin{array}{c}E^{\circ} p_{B H} \& H(e V) \\
{\left[\lambda_{\max }(n m)\right]}\end{array}$ & $\begin{array}{c}E^{\circ} \mathbf{p}_{\text {B3LYP }}(\mathrm{eV}) \\
{\left[\lambda_{\max }(\mathrm{nm})\right]}\end{array}$ & $\left|\Delta E_{B H} \& H\right|(e V)$ & $\left|\Delta E_{B 3 L Y P}\right|(e V)$ \\
\hline P1 & $2.53[489]$ & $2.79[443]$ & $2.30[540]$ & 0.26 & 0.23 \\
\hline SK2 & $2.22[559]$ & $2.86[433]$ & 2.08 [595] & 0.64 & 0.14 \\
\hline SK3 & $2.54[488]$ & $2.62[473]$ & $2.14[580]$ & 0.08 & 0.40 \\
\hline SK4 & $2.49[498]$ & $2.48[501]$ & $1.92[614]$ & 0.01 & 0.57 \\
\hline
\end{tabular}

The BH \& H is considerably successful in predicting the optical transition energies of dyes SK3 and SK4, where deviations from the experimentally measured spectrum are as low as 0.08 and $0.01 \mathrm{eV}$, but less successful with dyes P1 and SK2, where the calculated $\mathrm{E}^{\circ \mathrm{P}}$ is higher than the experimental value by 
0.26 and $0.64 \mathrm{eV}$, respectively. The lowest transition has, in all cases, a major HOMO-LUMO component $(55 \%-87 \%)$ in the Kohn-Sham basis, with minor components arising from higher energy excitations, typically $\mathrm{HOMO}-1 \rightarrow \mathrm{LUMO}, \mathrm{HOMO}-1 \rightarrow \mathrm{LUMO}+1$ and $\mathrm{HOMO} \rightarrow \mathrm{LUMO}+2$. The description of the lowest singlet state (S1) by the B3LYP calculation is roughly similar to that of the BH \& $\mathrm{H}$, although the HOMO-LUMO component to the excitation is largely predominating $(>93 \%)$. The lowest transition in P1 and SK2 is identified by B3LYP with a lower absolute error $(0.21$ and $0.11 \mathrm{eV})$ than the BH \& H functional, whereas larger errors are found with SK3 and, particularly with SK4, which shows long range charge transfers with a high degree of spatial charge separation, as indicated by Electron Density Difference Maps (EDDM) (Scheme 2). Both the B3LYP and BH \& H functional agree in the description of the EDDMs, showing a shift in electron density from the triphenylamine core to the electron acceptor branches, where the maximum density is localized in the proximity of the cyano groups (P1 and SK2) or on the benzothiadiazole acceptor (SK3 and SK4). It can also be appreciated that, in branched dyes (P1, SK2, and SK4), the electronic excitation involves the two acceptor branches simultaneously. Thus, the electronic distribution resulting from the lowest, and usually most intense, electronic transition is favorable to a successful charge separation. The hole density is localized in the immediate proximity of the surface interacting with $\mathrm{NiO}$ via $\mathrm{COOH}$ groups. This causes photoexcitation of the electron to occur predominantly on the farthest from the $\mathrm{NiO}$ part of the molecule where scavenging of the electron by $\mathrm{I}_{3}{ }^{-}$is more favorable.

Functional

P1

$\mathrm{BH} \& \mathrm{H}$
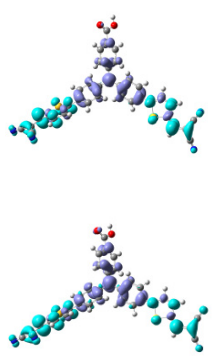

SK2
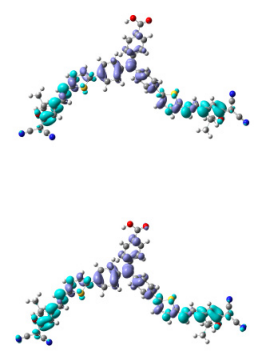

SK3
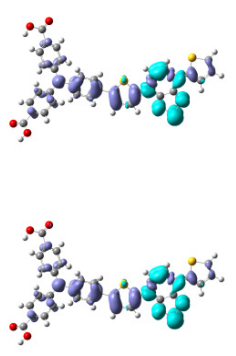

SK4
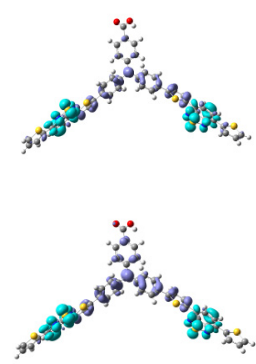

Scheme 2. Electron Density Difference Maps $($ EDDMs) (isovalue $=0.001$ ) of the main transition in the visible region calculated with a $6311 \mathrm{G}, \mathrm{d}$, + basis set obtained with the BH \& H (top row) and B3LYP (bottom row) functionals. DMSO solvent was described as a polarizable continuum model (PCM). Light blue and violet indicate an increased and a depleted electron density respectively.

The exciton binding energy (EBE) [38] was calculated [39] from the B3LYP data set, since BH \& H was found to give unrealistically high HOMO-LUMO gaps (Table S1, Supplementary Materials) as well as binding energies $(>1 \mathrm{eV})$. For the SK dyes, similar binding energies of the order of $0.33-0.38 \mathrm{eV}$ are found, being comparable to that of some efficient $n$-type push pull charge separators [40] recently reported in the literature. P1 displays the smallest EBE within the series with a value as small as $0.17 \mathrm{eV}$, comparable to some of the best $n$-type charge separators reported [41]. Smaller EBE favor separation of the electron-hole pair, and, consequently, charge injection into the semiconductor. The largest binding energy value of $0.38 \mathrm{eV}$ is found for the dye SK3, which means that a higher energy, usually provided by the local electric potential at the semiconductor/dye interface, or by collision with phonons, is needed in order to promote charge injection. The larger EBE of the SK series may constitute a disadvantage compared to the reference dye P1 for obtaining hole injection with high quantum yields.

\subsection{Photoelectrochemical Investigation in DSSCs}

The SK dyes together with reference compound $\mathbf{P 1}$ were tested as photosensitizers in $p$-type DSSCs. NiO photocathodes were fabricated by blading a $\mathrm{NiO}$ colloidal paste, obtained by dispersing commercial 25-nm $\mathrm{NiO}$ nanoparticles in terpineol, with ethylcellulose as an organic 
binder/densificating agent, followed by high temperature sintering on FTO (Fluorine-doped Tin Oxide) coated glass. The resulting photocurrent $(J)$ /photovoltage $(V)$ curves under AM 1.5 illumination (1 sun) are shown in Figure 4A and their main efficiency parameters are listed in Table 3.

Table 3. Photovoltaic parameters of investigated chromophores in $p$-type dye-sensitized solar cells (DSSCs).

\begin{tabular}{ccccc}
\hline Dye & $J_{\text {sc }}\left(\mathbf{m A} / \mathbf{c m}^{2}\right)$ & $V_{\text {oc }}(\mathbf{m V})$ & FF & PCE (\%) \\
\hline P1 & 1.14 & 95 & 0.32 & 0.035 \\
SK2 & 0.51 & 81 & 0.33 & 0.014 \\
SK3 & 0.54 & 82 & 0.33 & 0.015 \\
SK4 & 0.43 & 134 & 0.32 & 0.018 \\
\hline
\end{tabular}
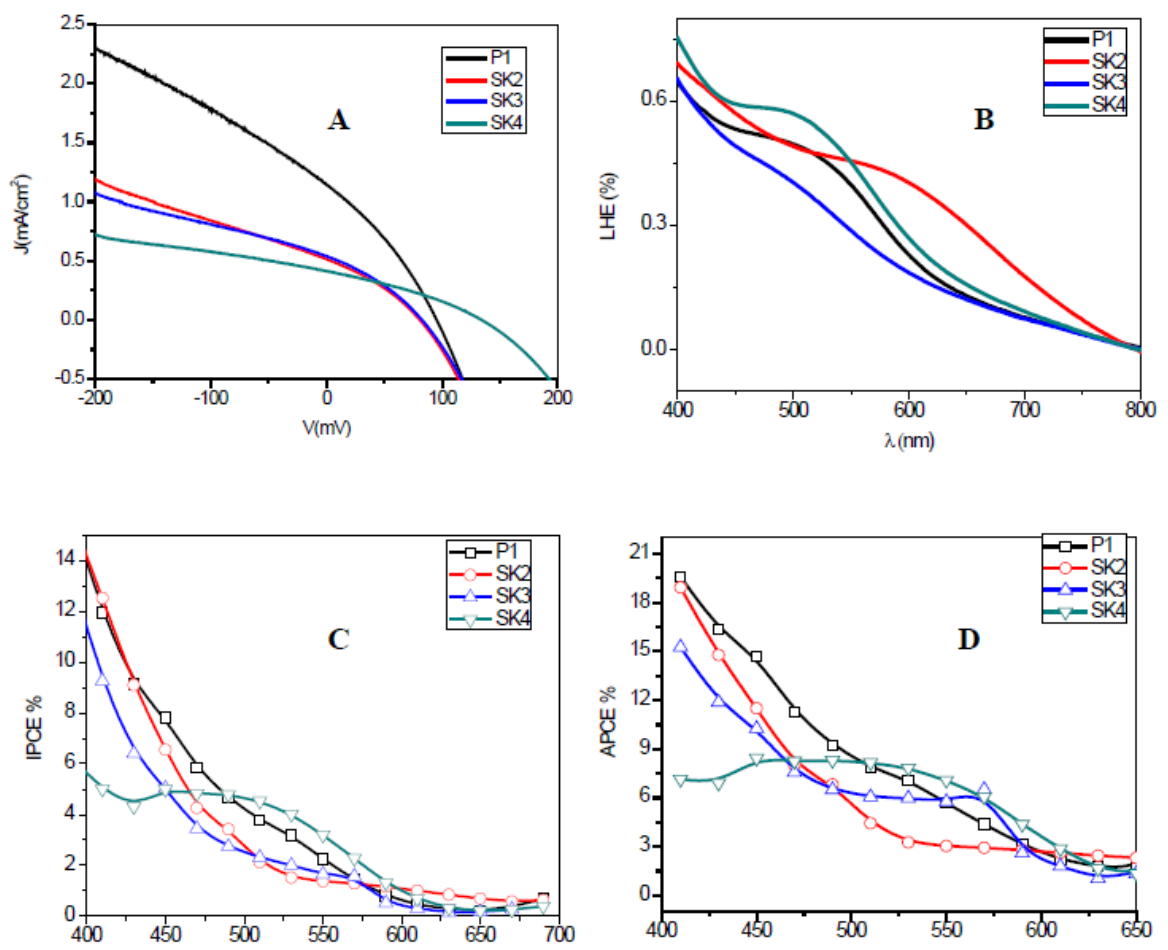

Figure 4. Photoelectrochemical and spectral properties of $p$-type DSSCs in the presence of $1 \mathrm{M} \mathrm{LiI}$ and $0.1 \mathrm{M} \mathrm{I}_{2}$ in acetonitrile: (A) current-voltage characteristics; (B) Light Harvesting Efficiency (LHE) $\left(\operatorname{LHE}(\lambda)=1-10^{-A(\lambda)}\right)$, where $\mathrm{A}(\lambda)$ is the background-subtracted absorbance of the dyed NiO films; (C) photoaction spectra (IPCE vs. $\lambda$ ); and (D) absorbed photon conversion efficiency spectra (APCE vs. 入).

The photoelectrochemical investigation was carried out with the iodide/triiodide redox couple (solution of $1.0 \mathrm{M} \mathrm{LiI}$ and $0.1 \mathrm{M} \mathrm{I}_{2}$ in $\mathrm{CH}_{3} \mathrm{CN}$ ). Dye SK4 produces the highest open circuit voltage $(133 \mathrm{mV})$, that is $c a .40 \mathrm{mV}$ higher than that of device sensitized by the other reference and novel dyes. The SK2 and SK3 molecules produced comparable $J_{\mathrm{sc}}\left(c a .0 .5 \mathrm{~mA} / \mathrm{cm}^{2}\right)$, which was, however, approximately half that of the reference $\mathbf{P 1}\left(c a .1 .1 \mathrm{~mA} / \mathrm{cm}^{2}\right)$. As a comparison, blank $\mathrm{NiO}$ cells without the sensitizer generated $c a .0 .25 \mathrm{~mA} / \mathrm{cm}^{2}$ at $0 \mathrm{~V}$, that is less than half of the cells sensitized by the SK series and $c a .1 / 4$ of the reference P1 (Figure S4, Supplementary Materials). In all cases the sloped $J / V$ characteristic at reverse (negative) bias is consistent with a small shunt resistance of the $\mathrm{NiO}$ films, causing charge leaks and losses by recombination. For instance, in the case of $\mathbf{P 1}$ the photoinjected charge extracted from the photocathode under short circuit conditions $(0 \mathrm{~V})$ is roughly one half that available at $-0.2 \mathrm{~V}$. Such a photocurrent loss upon moving from negative to positive potential is less marked for the SK series, which, giving rise to a smaller extent of hole injection, result in fewer charge 
leaks to the electrolyte. The overall PCE of P1-sensitized cells is about twice as large as that of the SK-based devices, mainly due to their lower photocurrents. In general, although not optimized, the efficiencies of the $\mathrm{NiO}$ sensitized solar cells recorded in this work are in agreement with the average performances reported so far in the literature for similar types of sensitized $p$-type electrodes.

To understand the nature of photocathodic current, the IPCE spectra of the $p$-type cells, under short circuit conditions were measured (Figure $4 \mathrm{C}$ ). Consistent with their spectral properties, all dyes displayed a strongest response in the blue region of the spectrum for $\lambda<450 \mathrm{~nm}$, reaching the best values of $c a .12 \%-14 \%$ for P1 and SK2. The higher IPCE in this narrow wavelength Vis region is motivated by both a direct contribution from the $\mathrm{I}^{-} / \mathrm{I}_{3}{ }^{-}$photochemistry and by a more efficient collection of the charge carriers generated in closer proximity of the electron collector by photons having a comparatively short penetration length into the film. The photoconversion then decreases by moving from the blue to the red region of the visible spectrum, showing a shoulder the $500-600 \mathrm{~nm}$ region, with values of $4 \%-5 \%$ in the case of P1 and SK4. Despite the opacity of the NiO electrodes, causing significant light scattering, and the strong competitive absorption of the iodine based electrolyte, in general the photoconversion appeared to be in a relatively good agreement with the Light Harvesting Efficiency (LHE) (Figure 4B) of the sensitized NiO photoelectrodes, confirming that the excited state of the dye is responsible for the observed photocurrent in the visible region of spectrum.

The LHE plot, with values of 50\%-60\% in the 550-450 nm region, showed that SK4 has here the best light harvesting performance, consistent with its relatively good IPCE response at these wavelengths. The absorbed monochromatic photon-to-current conversion efficiencies (APCE) spectra, obtained by dividing the corresponding IPCE spectra by the LHE of the respective photocathodes, are shown in Figure 4D. The low energy response of P1 and SK4 are similar, with APCE 10\% at $500 \mathrm{~nm}$. Interestingly, SK4 is able to yield a slightly more efficient conversion for $\lambda \geqslant 550 \mathrm{~nm}$, while P1 prevails below $480 \mathrm{~nm}$. As for the IPCE, the best APCE response is observed in the blue region of the spectrum, with values of $\sim 18 \%-20 \%$ for P1 and SK2.

Electrochemical impedance spectroscopy (EIS) was used to further investigate the comparative behavior of the chromophores in photovoltaic devices. All dyes were stable during potentiostatic measurements, which were performed at potentials between $-10 \mathrm{mV}$ and the $V_{\mathrm{oc}}$ of the cells. The $J / V$ curves after EIS measurements showed essentially the same performances found before the measurements, which allows to rule out substantial dye or cell degradation affecting the results. The EIS spectra (Figure S5, Supplementary Materials) could be well fitted with the equivalent circuit, comprising the serial resistance, the counter-electrode interface, the diffusion element accounting for electrolyte transport impedance in a thin layer cell, and the transmission line [42] (DX1 in Zview) which describes the transmission network of the NiO, applied by Zhang et al. $[17,18]$ to $p$-type DSSCs, comprising both the transport and the charge transfer resistance $\left(\mathrm{R}_{\mathrm{ct}}(\mathrm{NiO})\right)$ (recombination resistance) at the $\mathrm{NiO} /$ electrolyte interface.

The impedance response of the NiO based DSSC exhibited similar features, appearing as a small high frequency semicircle, due essentially to the counter-electrode electrochemical interface, followed by a much larger loop at lower frequencies, which bears the main contribution of the $\mathrm{NiO}$ /electrolyte interface. Indeed, the $J / V$ curves are essentially dominated by the charge transfer resistance of the $\mathrm{NiO}$, as can be appreciated by the comparison of the derivative $\left(\frac{\partial i}{\partial V}\right)$ of the $J / V$ curves and the inverse of the interfacial charge transfer resistance $\left(\mathrm{R}_{\mathrm{ct}}(\mathrm{NiO})\right)^{-1}$ (Figure $\left.5 \mathrm{~B}\right)$. This agreement is particularly good in the case of the SK series, for which the charge transfer resistance was the largely predominant contribution to the total cell resistance at each potential and varied, typically between 1000 and $200 \Omega$, depending on the voltage. Obviously, the lowest $\mathrm{R}_{\mathrm{ct}}(\mathrm{NiO})$ are in all cases found at the open-circuit voltage, due to hole accumulation into the mesoscopic film under open-circuit conditions.

The $\mathrm{NiO}$ capacitance (Figure 5A), calculated according to $\mathrm{C}=\mathrm{CPE}(\omega)^{n-1}$, where $\mathrm{n}$ is the exponent of the CPE admittance from the transmission line, in all cases variable between 0.9 and 0.84 , and $\omega$ is the frequency at the maximum of the large low frequency loop, was reasonably linear on a logarithmic 
scale, indicating a chemical capacitance [43] behavior determined by empty states in the valence bands or in surface states following a Boltzmann distribution near the valence band edge. The inspection of Figure 5 reveals that $\mathbf{P 1}$ is the dye which exhibits the lowest charge transfer resistance and highest capacitance, indicating a superior capability of hole injection.
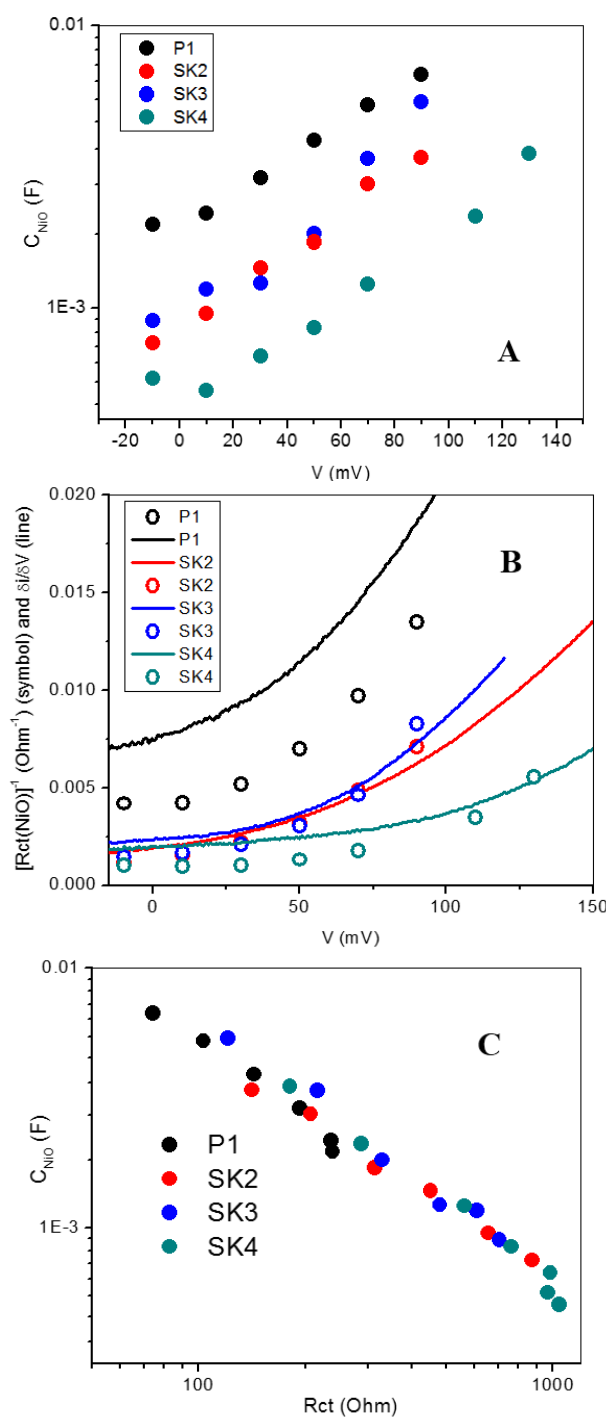

Figure 5. (A) Capacitance of sensitized $\mathrm{NiO}$ films at increasing potentials in the forward direction. (B) Reciprocal of the charge transfer resistance at the $\mathrm{NiO} /$ electrolyte interface (squares) compared to the derivative of the J/V curve (solid lines). (C) Chemical capacitance of $\mathrm{NiO}$ vs. interfacial charge transfer resistance in $p$-type DSSCs under study.

The representation of $\mathrm{R}_{\mathrm{ct}}(\mathrm{NiO})$ vs. $\mathrm{C}(\mathrm{NiO})$ on a logarithmic scale indicates that all the dyes behave intrinsically similarly to each other, as far as recombination kinetics are concerned, when compared at the same chemical capacitance of the $\mathrm{NiO}$. In other terms, the charge loss pathways involving direct dye $\mathrm{e}^{-} / \mathrm{h}^{+}$and hole recapture by $\mathrm{I}^{-}$occurred at comparable rates for all the dyes under investigation. Accordingly, the higher photovoltage observed for the SK4-sensitized device is likely due to a positive shift of the valence band edge of the $\mathrm{NiO}$ by $c a$. $30-40 \mathrm{mV}$, induced by the adsorption of the dye sensitizer, as can be observed by comparing the different voltages at which the similar capacitances are found, rather than by slower interfacial recombination kinetics. The voltage shift observed for SK4 in EIS under illumination is quantitatively consistent with the more positive onset of the anodic current observed for this moiety in the dark (Figure S6, Supplementary Materials). 


\section{Experimental Section}

\subsection{General Remarks}

NMR spectra were recorded with an instrument operating at $500.13\left({ }^{1} \mathrm{H}\right)$ and $125.77 \mathrm{MHz}$ $\left({ }^{13} \mathrm{C}\right)$. Flash chromatography was performed with silica gel $230-400$ mesh (60 ̊). Reactions conducted under a nitrogen atmosphere were performed in oven-dried glassware and monitored by thin-layer chromatography by using UV light $(254$ and $365 \mathrm{~nm})$ as a visualizing agent. 4-[Bis-(4-bromo-phenyl)-amino]-benzaldehyde and 4,4'-(4-bromophenylazanediyl)dibenzaldehyde were synthesised following procedure known in literature [44,45]. All other reagents were obtained from commercial suppliers at the highest purity and used without further purification. Anhydrous solvents were purchased from commercial suppliers and used as received. Extracts were dried with anhydrous $\mathrm{Na}_{2} \mathrm{SO}_{4}$ and filtered before removal of the solvent by evaporation.

\subsection{Synthesis of the p-Type Sensitizers}

\subsubsection{4-[Bis-(4-bromo-phenyl)-amino]-benzoic Acid (2)}

A procedure reported in the literature was adapted with some modifications [13]. The suspension of sodium hydroxide ( $62 \mathrm{mmol}, 2.5 \mathrm{~g}$ ) in $45 \mathrm{~mL}$ of ethanol was vigorously stirred for $20 \mathrm{~min}$ and then silver (I) oxide $(9.5 \mathrm{mmol}, 2.19 \mathrm{~g})$. Resulting mixture was stirred for another $20 \mathrm{~min}$ before 4-[bis-(4-bromo-phenyl)-amino]-benzaldehyde (1) $(1.2 \mathrm{mmol}, 550 \mathrm{mg})$ in $4 \mathrm{~mL}$ of toluene was slowly added. The resulting suspension was stirred at room temperature for $24 \mathrm{~h}$ and then neutralized with $\mathrm{HCl}(15 \%, 25 \mathrm{~mL})$ until formation of grey silver chloride precipitate was observed. The resulting solution was decanted and extracted with ethyl acetate $(3 \times 40 \mathrm{~mL})$. The organic phase was washed with water and dried. Thereafter the solvent was removed by rotary evaporation giving the desired acid 2 $(0.8 \mathrm{~g}, 78 \%)$ as white solid, which was used without further purification. ${ }^{1} \mathrm{H}$ NMR $\left(500 \mathrm{MHz}, \mathrm{DMSO}-d_{6}\right)$ : $\delta 6.90(\mathrm{~d}, J=8.5 \mathrm{~Hz}, 2 \mathrm{H}), 6.93(\mathrm{~d}, J=8.8 \mathrm{~Hz}, 4 \mathrm{H}), 7.44(\mathrm{~d}, J=8.8 \mathrm{~Hz}, 4 \mathrm{H}), 7.79(\mathrm{~d}, J=8.5 \mathrm{~Hz}, 2 \mathrm{H})$.

\subsubsection{4-\{Bis-[4-(5-formyl-thiophen-2-yl)-phenyl]-amino\}-benzoic Acid (3)}

The solution of benzoic acid $2(0.4 \mathrm{mmol}, 200.0 \mathrm{mg})$ and $\mathrm{Pd}(\mathrm{dppf}) \mathrm{Cl}_{2}(0.1 \mathrm{mmol}, 79 \mathrm{mg})$ in toluene $(5 \mathrm{~mL})$ was mixed with the solution of 5-formyl-2-thienylboronic acid $(1.2 \mathrm{mmol}, 187 \mathrm{mg})$ and $\mathrm{K}_{2} \mathrm{CO}_{3}$ $(2.5 \mathrm{mmol}, 355 \mathrm{mg})$ in methanol $(5 \mathrm{~mL})$. The resulting mixture was irradiated in the microwave oven at $80{ }^{\circ} \mathrm{C}$ for $20 \mathrm{~min}$ and then poured into a saturated solution of ammonium chloride $(60 \mathrm{~mL})$. After extraction with ethyl acetate $(3 \times 100 \mathrm{~mL})$, the combined organic phases were washed with brine, dried and then filtered over Celite and concentrated under reduced pressure. The crude residue was purified by column chromatography over silica gel using dichloromethane (DCM)/methanol 1:9 mixture as the eluent to give the product $(145 \mathrm{mg}, 62 \%)$ in form of yellow solid. m.p. $137-139{ }^{\circ} \mathrm{C},{ }^{1} \mathrm{H} \mathrm{NMR}(500 \mathrm{MHz}$, acetone- $\left.d_{6}\right): \delta 7.21(\mathrm{~d}, J=8.8 \mathrm{~Hz}, 2 \mathrm{H}), 7.28(\mathrm{~d}, J=8.7 \mathrm{~Hz}, 4 \mathrm{H}), 7.66(\mathrm{~d}, J=4.0 \mathrm{~Hz}, 2 \mathrm{H}), 7.83(\mathrm{~d}, J=8.7 \mathrm{~Hz}$, $4 \mathrm{H}), 7.98(\mathrm{~d}, J=4.0 \mathrm{~Hz}, 2 \mathrm{H}), 8.00(\mathrm{~d}, J=8.8 \mathrm{~Hz}, 2 \mathrm{H}), 9.94(\mathrm{~s}, 2 \mathrm{H}), 11.14(\mathrm{~s}, 1 \mathrm{H})$.

\subsubsection{4-(Bis(4-(5-((E)-2-(4-cyano-5-(dicyanomethylene)-2,2-dimethyl-2,5-dihydrofuran-3-yl)vinyl)} thiophen-2-yl)phenyl)amino)benzoic Acid (SK2)

To a solution of the intermediate $4(100 \mathrm{mg}, 0.2 \mathrm{mmol})$ and 2-(3-cyano-4,5,5-trimethylfuran-2 $(5 \mathrm{H})$-ylidene)malononitrile $(77.2 \mathrm{mg}, 0.4 \mathrm{mmol})$ in ethanol $(20 \mathrm{~mL})$ was added catalytic amount of ammonium acetate $(8 \mathrm{mg}, 0.1 \mathrm{mmol})$ in $2 \mathrm{~mL}$ of acetic acid. Reaction mixture was refluxed under nitrogen atmosphere for $100 \mathrm{~h}$. Afterwards, organic solvent was evaporated under reduced pressure and resulted crude product was washed with ethyl acetate to give the desired dye SK2 $(75 \mathrm{mg}$, $74 \%$ ) in form of dark violet solid. m.p. $252-253{ }^{\circ} \mathrm{C} .{ }^{1} \mathrm{H}$ NMR $\left(500 \mathrm{MHz}, \mathrm{DMSO}-d_{6}\right): \delta 12.75(\mathrm{~s}, 1 \mathrm{H})$, $8.17(\mathrm{~d}, J=16 \mathrm{~Hz}, 2 \mathrm{H}), 7.92(\mathrm{~d}, J=8 \mathrm{~Hz}, 2 \mathrm{H}), 7.87(\mathrm{~d}, J=4 \mathrm{~Hz}, 2 \mathrm{H}), 7.84(\mathrm{~d}, J=8.0 \mathrm{~Hz}, 4 \mathrm{H}), 7.73(\mathrm{~d}$, $J=4 \mathrm{~Hz}, 2 \mathrm{H}), 7.2(\mathrm{~d}, J=9 \mathrm{~Hz}, 4 \mathrm{H}), 7.16(\mathrm{~d}, J=9 \mathrm{~Hz}, 2 \mathrm{H}), 6.83(\mathrm{~d}, J=16 \mathrm{~Hz}, 2 \mathrm{H}), 1.81(\mathrm{~s}, 12 \mathrm{H}) .{ }^{13} \mathrm{C} \mathrm{NMR}$ (acetone- $d 6$ ): $\delta 26.7,54.9,98.3,99.2,100.2,112.4,113.4,114.2,114.3,123.9,126.5,127.2,129,129.6,132.5$, 
139.5, 140.3, 141.7, 148.2, 151.3, 152.2, 168.1, 175.9, 178.2. $v_{\max }\left(\mathrm{cm}^{-1}\right) 3583,3476,3007,2310,1738,1590$, 1373, 1217. Found: $\mathrm{C}, 70.11 ; \mathrm{H}, 4.19 ; \mathrm{N}, 11.60 . \mathrm{C}_{51} \mathrm{H}_{33} \mathrm{~N}_{7} \mathrm{O}_{4} \mathrm{~S}_{2}$ requires: $\mathrm{C}, 70.25 ; \mathrm{H}, 3.81 ; \mathrm{N}, 11.24$.

\subsubsection{4-(5-Bromothiophen-2-yl)-7-(thiophen-2-yl)benzo[1,2,5]thiadiazole (5)}

To a solution of 4,7-di-2-thienyl-2,1,3-benzothiadiazole (4) [46] (350 mg, $1.17 \mathrm{mmol})$ in a $100 \mathrm{~mL}$ of acetic acid- $\mathrm{CH}_{2} \mathrm{Cl}_{2}$ 1:1 mixture, was added N-bromosuccinimide (NBS) (229 mg, $1.28 \mathrm{mmol}$ ) in DCM by small portions over $30 \mathrm{~min}$. The resulting reaction mixture was stirred overnight, then poured into water $(100 \mathrm{~mL})$ and the separated organic layer was dried, filtered and concentrated in vacuum. Obtained crude product was purified by flash column chromatography on silica gel (DCM-hexane $=1: 4$ ) giving a target benzothiadiazole derivative (5) in form of bright orange solid with $70 \%$ yield $(310 \mathrm{mg}, 0.8 \mathrm{mmol}) .{ }^{1} \mathrm{H}$ NMR $\left(500 \mathrm{MHz}, \mathrm{CDCl}_{3}\right): \delta 8.12(\mathrm{~d}, 1 \mathrm{H}),, 7.88(\mathrm{~d}, 1 \mathrm{H}), 7.8(\mathrm{~m}, 2 \mathrm{H})$, $7.46(\mathrm{~d}, 1 \mathrm{H}), 7.22(\mathrm{~d}, 1 \mathrm{H}), 7.15(\mathrm{~d}, 1 \mathrm{H})$.

\subsubsection{4-(5-(4,4,5,5-Tetramethyl-1,3,2-dioxaborolan-2-yl)thiophen-2-yl)-7-(thiophen-2-yl)benzo[c]} $[1,2,5]$ thiadiazole $(6)$

Schlenk flask was charged with 4,7-di(thiophen-2-yl)benzo[c][1,2,5]thiadiazole (5) (550 mg, $1.45 \mathrm{mmol}$ ), potassium acetate $(440 \mathrm{mg}, 4.48 \mathrm{mmol}$ ) and bis(pinacolato)diboron (490 mg, $1.93 \mathrm{mmol}$ ) together with the catalytic amount of $\mathrm{Pd}(\mathrm{dppf}) \mathrm{Cl}_{2}(0.05 \mathrm{mmol}, 39 \mathrm{mg})$ and $15 \mathrm{~mL}$ of dry dioxane. Resulting mixture was heated at reflux under argon atmosphere for $24 \mathrm{~h}$ then poured in water, extracted with ethyl acetate $(3 \times 50 \mathrm{~mL})$ and dried. After organic solvent was evaporated under reduced pressure, crude product was purified on silica gel using $\mathrm{CH}_{2} \mathrm{Cl}_{2}$-cyclohexane 1:4 as eluent. Product was obtained in form of brownish orange solid $\left(318 \mathrm{mg}, 55 \%\right.$ yield). m.p. $168{ }^{\circ} \mathrm{C}-170{ }^{\circ} \mathrm{C}$. ${ }^{1} \mathrm{H} \mathrm{NMR}\left(500 \mathrm{MHz}, \mathrm{CDCl}_{3}\right): \delta=8.18(\mathrm{~d}, J=4 \mathrm{~Hz}, 1 \mathrm{H}) 8.13(\mathrm{~m}, 1 \mathrm{H}), 7.92(\mathrm{~d}, J=8 \mathrm{~Hz}, 1 \mathrm{H}), 7.87(\mathrm{~d}$, $J=8 \mathrm{~Hz}, 1 \mathrm{H}), 7.72(\mathrm{~d}, J=3 \mathrm{~Hz}, 1 \mathrm{H}), 7.45(\mathrm{~m}, 1 \mathrm{H}), 7.21(\mathrm{~m}, 1 \mathrm{H}), 1.38(\mathrm{~s}, 12 \mathrm{H}) .{ }^{13} \mathrm{C} \mathrm{NMR}\left(\mathrm{CDCl}_{3}\right)$ : $\delta=152.66(\mathrm{CH}), 152.63(\mathrm{CH}), 145.89(\mathrm{CH}), 139.32(\mathrm{CH}), 137.89(\mathrm{C}), 128.65(\mathrm{C}), 128.03(\mathrm{C}), 127.67(\mathrm{C})$, $126.97(\mathrm{C}), 126.48(\mathrm{CH}), 126.37(\mathrm{C}), 125.83(\mathrm{CH}), 125.75(\mathrm{C}), 84.26(\mathrm{CH} 3), 24.79(\mathrm{C}) \mathrm{ppm}$. Found C, 56.39; $\mathrm{H}, 4.60 ; \mathrm{N}, 6.29 . \mathrm{C}_{20} \mathrm{H}_{19} \mathrm{BN}_{2} \mathrm{O}_{2} \mathrm{~S}_{3}$ requires: $\mathrm{C}, 56.34 ; \mathrm{H}, 4.49 ; \mathrm{N}, 6.57$.

\subsubsection{4,4'-(4-(5-(7-(Thiophen-2-yl)benzo[c][1,2,5]thiadiazol-4-yl)thiophen-2-yl)phenylazanediyl)} dibenzaldehyde (7)

4,4'-(4-Bromophenylazanediyl)dibenzaldehyde (114 mg, $0.3 \mathrm{mmol})$, benzothiadaizole derivative 6 $(130 \mathrm{mg}, 0.31 \mathrm{mmol})$, a catalytic amount of $\mathrm{Pd}(\mathrm{dppf}) \mathrm{Cl}_{2}(0.019 \mathrm{mmol}, 18 \mathrm{mg})$ and a solution of $\mathrm{K}_{2} \mathrm{CO}_{3}$ ( $400 \mathrm{mg}, 2.9 \mathrm{mmol})$ in water $(3 \mathrm{~mL})$ were charged into Schlenk flask and then dissolved in $15 \mathrm{~mL}$ of dry dimethoxyethane (DME). Reaction mixture was refluxed under argon atmosphere for $15 \mathrm{~h}$ and after cooling down to the room temperature it was washed with water, dried and concentrated under vacuum. Crude product was purified by column chromatography on silica gel using ethyl acetate-cyclohexane $=2: 7$ as the eluent. The pure intermediate $7(55 \mathrm{mg}, 30 \%$ yield $)$ was obtained in form of bright red solid. m.p. $173{ }^{\circ} \mathrm{C}-175^{\circ} \mathrm{C} .{ }^{1} \mathrm{H}$ NMR $\left(500 \mathrm{MHz}, \mathrm{CDCl}_{3}\right): \delta=9.91(\mathrm{~s}, 2 \mathrm{H}), 8.12(\mathrm{dd}$, $J=8.0 ; 15 \mathrm{~Hz}, 2 \mathrm{H}), 7.86(\mathrm{~s}, 1 \mathrm{H}), 7.81(\mathrm{~d}, J=17.0 \mathrm{~Hz}, 4 \mathrm{H}), 7.68(\mathrm{~d}, J=17.0 \mathrm{~Hz}, 2 \mathrm{H}), 7.45(\mathrm{~d}, J=8.0 \mathrm{~Hz}$, $1 \mathrm{H}), 7.39(\mathrm{~d}, J=8.0 \mathrm{~Hz}, 1 \mathrm{H}), 7.24(\mathrm{~d}, J=17.0 \mathrm{~Hz}, 4 \mathrm{H}), 7.21(\mathrm{~d}, J=8.0 \mathrm{~Hz}, 1 \mathrm{H}), 7.17(\mathrm{~d}, J=17.0 \mathrm{~Hz}$, $2 \mathrm{H}) .{ }^{13} \mathrm{C} \mathrm{NMR}\left(\mathrm{CDCl}_{3}\right): \delta=191.4,153.5,153.4,152.6,145.8,140.18,139.9,132.7,132.4,132.2,129.5,128.9$, 128.5, 128.2, 127.89, 127.83, 126.9, 126.6, 126.5, 126.3, 125.2, 123.9 ppm. Found: C, 67.84; H, 3.63; N, 7.33. $\mathrm{C}_{34} \mathrm{H}_{21} \mathrm{~N}_{3} \mathrm{O}_{2} \mathrm{~S}_{3}$ requires: $\mathrm{C}, 68.09 ; \mathrm{H}, 3.53 ; \mathrm{N}, 7.01$.

3.2.7. 4-(Bis(4-(5-(7-(thiophen-2-yl)benzo[c][1,2,5]thiadiazol-4-yl)thiophen-2-yl)phenyl)amino) benzaldehyde (8)

4-[Bis-(4-bromo-phenyl)-amino]-benzaldehyde (1) $(100 \mathrm{mg}, 0.232 \mathrm{mmol})$ and benzothiadaizole derivative 6 ( $213 \mathrm{mg}, 0.5 \mathrm{mmol})$ and $\mathrm{K}_{2} \mathrm{CO}_{3}(691 \mathrm{mg}, 5 \mathrm{mmol})$ were dissolved in $5 \mathrm{~mL}$ of water and charged into Schlenk flask together with the catalytic amount of $\mathrm{Pd}(\mathrm{dppf}) \mathrm{Cl}_{2}(0.02 \mathrm{mmol}, 19 \mathrm{mg})$ and then dissolved in $15 \mathrm{~mL}$ of dry DME. Reaction mixture was refluxed under argon atmosphere for 
$15 \mathrm{~h}$. After cooling to the room temperature it was washed with water, dried and concentrated under vacuum. Crude product was washed with ethyl acetate and filtered. The desired intermediate 8 was obtained as dark red solid (70 mg, yield $45 \%)$. m.p. $189{ }^{\circ} \mathrm{C}-190{ }^{\circ} \mathrm{C}$ (decomp.). ${ }^{1} \mathrm{H}$ NMR $(500 \mathrm{MHz}$, $\left.\mathrm{CDCl}_{3}\right): \delta=9.88(\mathrm{~s}, 1 \mathrm{H}), 8.14(\mathrm{~d}, J=8.0,4 \mathrm{H}), 7.9(\mathrm{~s}, 1 \mathrm{H}), 7.77(\mathrm{~d}, J=17.0 \mathrm{~Hz}, 2 \mathrm{H}), 7.69(\mathrm{~d}, J=17.0 \mathrm{~Hz}$, $4 \mathrm{H}), 7.47(\mathrm{~d}, J=8.0 \mathrm{~Hz}, 2 \mathrm{H}), 7.41(\mathrm{~d}, J=8.0 \mathrm{~Hz}, 2 \mathrm{H}), 7.23(\mathrm{~d}, J=17.0 \mathrm{~Hz}, 4 \mathrm{H}), 7.22(\mathrm{~d}, J=8.0 \mathrm{~Hz}, 2 \mathrm{H})$, $7.19(\mathrm{~d}, J=17.0 \mathrm{~Hz}, 2 \mathrm{H}) .{ }^{13} \mathrm{C}$ NMR $\left(\mathrm{CDCl}_{3}\right): \delta=191.4,153.6,153.5,153.4,146.4,145.3,140.2,139.5$, 132.3, 131.7, 130.9, 129.6, 128.9, 128.4, 127.9, 127.8, 127.7, 127.0, 126.8, 126.6, 126.2, 124.9, 121.6 ppm. Found C 64.50; $\mathrm{H} 2.88 ; \mathrm{N}$ 7.91. $\mathrm{C}_{47} \mathrm{H}_{27} \mathrm{~N}_{5} \mathrm{OS}_{6}$ requires: $\mathrm{C}, 64.87 ; \mathrm{H}, 3.13 ; \mathrm{N}, 8.05$.

\subsubsection{4,4'-(4-(5-(7-(Thiophen-2-yl)benzo[c][1,2,5]thiadiazol-4-yl)thiophen-2-yl)phenylazanediyl)} dibenzoic Acid (SK3)

A suspension of sodium hydroxide $(600 \mathrm{mg}, 15 \mathrm{mmol})$ in $10 \mathrm{~mL}$ of ethanol was vigorously stirred for $15 \mathrm{~min}$ before $\mathrm{Ag}_{2} \mathrm{O}$ ( $208 \mathrm{mg}, 0.8 \mathrm{mmol}$ ) was added. After another $15 \mathrm{~min}$, dibenzaldehyde 7 ( $50 \mathrm{mg}$, $0.08 \mathrm{mmol}$ ) in toluene was added dropwise to the solution. Reaction mixture was stirred overnight at room temperature and quenched by the slow addition of $1 \mathrm{M} \mathrm{HCl}$ solution, then it was extracted with $\mathrm{CH}_{2} \mathrm{Cl}_{2}(3 \times 75 \mathrm{~mL})$. Combined organic layers were washed with water and dried. After evaporation of solvent under reduced pressure resulting crude product was washed with diethyl ether to give final compound SK3 in form of dark red solid (40 mg. 87\% yield). m.p. $215^{\circ} \mathrm{C}-217^{\circ} \mathrm{C} .{ }^{1} \mathrm{H}$ NMR $(500 \mathrm{MHz}$, DMSO-d6): $\delta=8.20(\mathrm{t}, J=9 \mathrm{~Hz}, 2 \mathrm{H}), 8.17(\mathrm{~d}, J=8 \mathrm{~Hz}, 1 \mathrm{H}), 8.12(\mathrm{~d}, J=8.0 \mathrm{~Hz}, 1 \mathrm{H}), 7.92(\mathrm{~d}, J=8.7 \mathrm{~Hz}$, $4 \mathrm{H}), 7.80(\mathrm{~d}, J=8.5 \mathrm{~Hz}, 2 \mathrm{H}), 7.78(\mathrm{~d}, J=5.1 \mathrm{~Hz}, 1 \mathrm{H}), 7.67(\mathrm{~d}, J=4.0 \mathrm{~Hz}, 1 \mathrm{H}), 7.29(\mathrm{~d}, J=8.7 \mathrm{~Hz}, 1 \mathrm{H})$, $7.22(\mathrm{~d}, J=8.5 \mathrm{~Hz}, 2 \mathrm{H}) 7.15(\mathrm{~d}, J=8.7 \mathrm{~Hz}, 4 \mathrm{H}) .{ }^{13} \mathrm{C}$ NMR (DMSO-d6): $\delta=168.1,153.0,152.9,151.4$, 146.7, 145.7, 139.8, 138.9, 132.5, 131.4, 130.1, 129.7, 129.5, 128.8, 128.3, 127.7, 127.2, 126.9, 126.4, 126.3, 126.0, 125.9, 124.0 ppm. $v_{\max }\left(\mathrm{cm}^{-1}\right) 3456,2970,2281,1738,1494,1366,1217$. Found: C, 64.36; H, 3.74; $\mathrm{N}$, 6.94. $\mathrm{C}_{34} \mathrm{H}_{21} \mathrm{~N}_{3} \mathrm{O}_{4} \mathrm{~S}_{3}$ requires: $\mathrm{C}, 64.64 ; \mathrm{H}, 3.35 ; \mathrm{N}, 6.65$.

\subsubsection{4-(Bis(4-(5-(7-(thiophen-2-yl)benzo[c][1,2,5]thiadiazol-4-yl)thiophen-2-yl)phenyl)amino)} benzoic Acid (SK4)

To the vigorously stirred suspension of $\mathrm{NaOH}(300 \mathrm{mg}, 7.5 \mathrm{mmol})$ in $10 \mathrm{~mL}$ of ethanol was added silver (I) oxide ( $205 \mathrm{mg}, 0.8 \mathrm{mmol}$ ). Mixture was stirred for $15 \mathrm{~min}$ before adding benzaldehyde $8\left(50 \mathrm{mg}, 0.057 \mathrm{mmol}\right.$ ) in $\mathrm{CH}_{2} \mathrm{Cl}_{2}$. Reaction mixture was stirred overnight at the room temperature and quenched by the slow addition of $1 \mathrm{M} \mathrm{HCl}$ solution, extracted with ethyl acetate $(3 \times 75 \mathrm{~mL})$ and then combined organic layers were washed with water and dried. After evaporation of solvents, crude product was washed with dichloromethane. SK4 dye was obtained in form of black-red solid $(40 \mathrm{mg}$, $90 \%$ yield). m.p. $>285^{\circ} \mathrm{C}$ (decomp.). ${ }^{1} \mathrm{H}$ NMR $\left(500 \mathrm{MHz}, \mathrm{CDCl}_{3}\right): \delta=8.22(\mathrm{~d}, J=3.9 \mathrm{~Hz}, 2 \mathrm{H}), 8.20$ $(\mathrm{d}, J=3.9 \mathrm{~Hz}, 2 \mathrm{H}), 8.18(\mathrm{~s}, 2 \mathrm{H}), 8.14(\mathrm{~d}, J=8.3 \mathrm{~Hz}, 2 \mathrm{H}), 7.88(\mathrm{~d}, J=8.7 \mathrm{~Hz}, 2 \mathrm{H}), 7.81(\mathrm{~d}, J=8.5 \mathrm{~Hz}$, $4 \mathrm{H}), 7.79(\mathrm{~d}, J=5.5 \mathrm{~Hz}, 2 \mathrm{H}), 7.68(\mathrm{~d}, J=4.1 \mathrm{~Hz}, 2 \mathrm{H}), 7.31(\mathrm{t}, J=8.8 \mathrm{~Hz}, 2 \mathrm{H}), 7.23(\mathrm{~d}, J=8.5 \mathrm{~Hz}, 4 \mathrm{H})$, $7.11(\mathrm{~d}, J=8.7 \mathrm{~Hz}, 2 \mathrm{H}) .{ }^{13} \mathrm{C}$ NMR (DMSO- $\left.d_{6}\right): \delta=169.07,153.5,153.3,151.8,151.7,146.97,145.8,142.2$, 132.0, 131.5, 130.8, 129.6, 128.9, 128.2, 127.8, 127.7, 126.9, 126.7, 126.6, 126.3, 126.1, 124.6, 122.3 ppm. $v_{\max }\left(\mathrm{cm}^{-1}\right) 3472,2976,2110,1738,1546,1372,1254$. Found C 63.88, H 3.44, N 7.68. $\mathrm{C}_{47} \mathrm{H}_{27} \mathrm{~N}_{5} \mathrm{O}_{2} \mathrm{~S}_{6}$ requires: $\mathrm{C}, 63.70 ; \mathrm{H}, 3.07 ; \mathrm{N}, 7.90$.

\subsection{Solar Cell Assembly}

$\mathrm{NiO}$ films were prepared by grounding $7.5 \mathrm{~g}$ of $\mathrm{NiO}$ nanoparticles (Inframat, nominal size $25 \mathrm{~nm}$ ) in a mortar in the presence of $200 \mathrm{~mL}$ of acetilacetone. $100 \mathrm{~mL}$ of terpineol were then added, followed by $10 \mathrm{~g}$ of ethlycellulose dissolved in $110 \mathrm{~mL}$ of absolute ethanol. The resulting mixture was homogenized by stirring and sonication in an ultrasonic bath. Ethanol was evaporated under reduced pressure leaving a dense paste constituted by terpineol, ethylcellulose and $\mathrm{NiO}$ nanoparticles. The resulting paste could be spread by blading onto well cleaned FTO glass to form, after drying and high temperature sintering, the $\mathrm{NiO}$ thin films. The temperature program adopted for drying and sintering in air was the following: $10 \mathrm{~min}$ at $120^{\circ} \mathrm{C}$, followed by a ramp $\left(15^{\circ} \mathrm{C} / \mathrm{min}\right)$ to $450{ }^{\circ} \mathrm{C}$ which 
were maintained for $30 \mathrm{~min}$. A subsequent ramp $\left(10^{\circ} \mathrm{C} / \mathrm{min}\right)$ brought the temperature from $450{ }^{\circ} \mathrm{C}$ to $550^{\circ} \mathrm{C}$ which were kept constant for further $20 \mathrm{~min}$. Cooling occurred naturally, by interrupting the heating. Sensitization of the resulting $\mathrm{NiO}$ electrodes, having an active surface of $0.25 \mathrm{~cm}^{2}$, was carried out overnight in the dark, by immersion in the DMSO solutions at the concentration of $2 \times 10^{-4} \mathrm{M}$ of the selected sensitizers. Solar cells were fabricated by clamping the sensitized $\mathrm{NiO}$ photocathode with a platinum coated FTO counter electrode (Chimet, Badia al Pino, Italy). The electrolyte was $1 \mathrm{M}$ $\mathrm{LiI} / 0.1 \mathrm{M} \mathrm{I}_{2}$ in acetonitrile.

\subsection{Spectroscopic, Electrochemical, and Photoelectrochemical Measurements}

UV-Vis spectra of sensitized $\mathrm{NiO}$ thin films, collected in transmission mode, were recorded on a JASCO V570 UV-Vis-NIR spectrophotometer (Jasco Analytical instruments, Easton, MD, USA). UV-Vis spectra in solution were obtained with a V-570 JASCO spectrophotometer (Jasco Analytical instruments, Easton, MD, USA). Emission spectra were recorded FP6200JASCO spectrofluorometer. $\mathrm{TBAlClO}_{4}$ 0.1 DMSO.

Cyclic voltammetry of the dye dissolved in $0.1 \mathrm{M}$ solution of tetrabutylammonium perchlorate (Fluka, electrochemical grade, 99.0\%) in anhydrous DMSO (Sigma-Aldrich) as the supporting electrolyte was carried out at a glassy carbon working electrode with a PARSTA2273 potentiostat in a two-chamber three-electrodeelectrochemical cell with a scan rate of $50 \mathrm{mVs}^{-1}$. Potentials are referred to the ferrocenium/ferrocene $\left(\mathrm{Fc}^{+} / \mathrm{Fc}\right)$ couple as internal reference. An Ecochemie PGSTAT 302/N electrochemical workstation equipped with the FRA 2 Frequency Response Analyzer and running under either GPES or Nova software was used for collecting both the JV characteristics and the EIS response of the p-DSSCs. Solar cells were illuminated under simulated solar conditions (Am $1.5 \mathrm{G} 100 \mathrm{~mW} / \mathrm{cm}^{2}$ ) generated by an ABET sun simulator. J/V curves were recorded by linear scan voltammetry, using a scan rate of $5 \mathrm{mV} / \mathrm{s}$. Every cell was left to equilibrate under illumination until a superimposable J/V response was obtained upon subsequent scans. Curves reported in this work, representative of the average performance of three cells, are those measured after steady state was achieved. Potentiostatic EIS data were collected on a single cell at various voltages under illumination by applying a $10 \mathrm{mV}$ sinusoidal frequency variable from $10^{5}$ to $10^{-2} \mathrm{~Hz}$. Impedance data were fitted with Zview.

IPCE data were collected under monochromatic illumination, having a band pass of $10 \mathrm{~nm}$, generated by an Applied Photophysics monochromator coupled to a $175 \mathrm{~W}$ Luxtel Xe arc lamp. Short circuit photocurrents were recorded on an Agilent 34401A multimeter. Incident irradiance was measured with a calibrated Centronic OSD 7Q silicon photodiode having an active area of $1 \mathrm{~cm}^{2}$.

\subsection{Computational Studies}

Optimized ground state geometry of the $p$-type dyes were obtained at the DFT-B3LYP level by using a $631 \mathrm{G}^{*}$ basis set. The DFT calculation was carried out on pre-optimized structures at the PM6 level. Time dependent (TDDFT) calculations in the presence of DMSO solvent, treated as continuum polarizable medium, were carried out on the optimized structures by considering the two different B3LYP and BH \& $\mathrm{H}$ functionals with the $6311 \mathrm{G}^{*}$ basis set incorporating also diffuse functions (+). All calculations were carried out with Gaussian 09 A02 [32] on multi-core computers. Structures and isodensity surfaces were graphically visualized with Gaussview 5. Electron Density Difference Maps (EDDMs) were generated with GaussSum 2.2 [47].

\section{Conclusions}

New $p$-type photosensitizers based on organic linear and di-branched donor-acceptor systems bearing tryphenylamine as a donor and strong electron-acceptor Dalton's (SK2) or benzothiadiazole (SK3 and SK4) groups were synthesized and characterized by steady state spectroscopic, electrochemical, and computational studies. All the dyes under investigation exhibited strong charge transfer bands in the visible regions with ground and excited state energetic which are favorable to the 
sensitization of $\mathrm{NiO}$ electrodes. The computational investigation revealed a clear directionality of the lowest excited state exhibiting a marked charge transfer character, shifting the electron density from the donor core to the acceptor branches, an electronic situation that is favorable to the hole injection in $p$-type semiconductors such as $\mathrm{NiO}$. However, the exciton binding energy, i.e., the energy of the bound electron-hole pair, is about twice as large as that of a known literature standard (P1), suggesting that a more difficult charge separation in the new dyes might occur.

When tested as photosensitizers in $p$-type DSSCs, the SK series was able to successfully sensitize $\mathrm{NiO}$ electrodes, resulting in photocurrents that are about half that of P1-based cells. The charge recombination kinetics, probed by considering the charge transfer resistance at the $\mathrm{NiO} /$ electrolyte interface at a comparable chemical capacitance, showed that the dyes behaved similarly under this respect and that the higher photovoltage observed for the device based on SK4 dye is seemingly due to a positive shift of the valence band edge, consistent with the shift in the anodic threshold measured in the dark. The fact that similar recombination resistances were found at a comparable photohole density in the $\mathrm{NiO}$ corroborates the indication, gained by DFT studies, that the superior performance, particularly in photocurrent, of $\mathbf{P 1}$ may be ascribed to a superior charge separation capability originating by its smaller exciton binding energy. Future designs of dyes for $p$-type sensitization will take this parameter into consideration for achieving a more effective charge separation.

Supplementary Materials: CV plot, normalized absorption and emission spectra, DFT isodensity plots of HOMOs and LUMOs, HOMO-LUMO energy gaps and excition binding energies, dark currents and EIS spectra of p-DSSC, ${ }^{1} \mathrm{H}$ and ${ }^{13} \mathrm{C}$ NMR spectra of intermediates and dyes. The following are available online at www.mdpi.com/1996-1073/9/1/33/s1.

Acknowledgments: The authors thank the Ministero dell'Università e della Ricerca (MIUR-PRIN) (grants No. 2008CSNZFR and 20104XET32) for financial support.

Author Contributions: Norberto Manfredi and Alessandro Abbotto conceived and designed the molecules and the synthesis; Svitlana Karamshuk performed the synthesis; Matteo Salamone and Riccardo Ruffo designed and performed electrochemical analysis; Stefano Carli and Stefano Caramori performed the computational calculations; Stefano Caramori and Carlo-Alberto Bignozzi designed and prepared the photovoltaic devices.

Conflicts of Interest: The authors declare no conflict of interest.

\section{References}

1. O'Regan, B.; Gratzel, M. A low-cost, high-efficiency solar cell based on dye-sensitized colloidal $\mathrm{TiO}_{2}$ films. Nature 1991, 353, 737-740. [CrossRef]

2. International Energy Agency (IEA). Potential for Building Integrated Photovoltaics; Report IEA PVPS Task 7; NET Ltd.: St. Ursen, Switzerland, 2002.

3. Giordano, F.; Guidobaldi, A.; Petrolati, E.; Vesce, L.; Riccitelli, R.; Reale, A.; Brown, T.M.; di Carlo, A. Realization of high performance large area Z-series-interconnected opaque dye solar cell modules. Prog. Photovolt. Res. Appl. 2013, 21, 1653-1658. [CrossRef]

4. Mathew, S.; Yella, A.; Gao, P.; Humphry-Baker, R.; CurchodBasile, F.E.; Ashari-Astani, N.; Tavernelli, I.; Rothlisberger, U.; NazeeruddinMd, K.; Grätzel, M. Dye-sensitized solar cells with $13 \%$ efficiency achieved through the molecular engineering of porphyrin sensitizers. Nat. Chem. 2014, 6, 242-247. [CrossRef] [PubMed]

5. Green, M.A. Third Generation Photovoltaics: Advanced Solar Energy Conversion; Springer-Verlag: Heidelberg, Germany, 2003.

6. Hagfeldt, A.; Boschloo, G.; Sun, L.; Kloo, L.; Pettersson, H. Dye-Sensitized Solar Cells. Chem. Rev. 2010, 110, 6595-6663. [CrossRef] [PubMed]

7. Lide, D.R. Handbook of Chemistry and Physics, 90th ed.; CRC Press: Boca Raton, FL, USA, 2010.

8. Odobel, F.; Pellegrin, Y.; Gibson, E.A.; Hagfeldt, A.; Smeigh, A.L.; Hammarström, L. Recent advances and future directions to optimize the performances of $p$-type dye-sensitized solar cells. Coord. Chem. Rev. 2012, 256, 2414-2423. [CrossRef] 
9. Morandeira, A.; Boschloo, G.; Hagfeldt, A.; Hammarström, L. Coumarin 343-NiO Films as Nanostructured Photocathodes in Dye-Sensitized Solar Cells: Ultrafast Electron Transfer, Effect of the $\mathrm{I}^{3-} / \mathrm{I}^{-}$Redox Couple and Mechanism of Photocurrent Generation. J. Phys. Chem. C 2008, 112, 9530-9537. [CrossRef]

10. Zhu, H.; Hagfeldt, A.; Boschloo, G. Photoelectrochemistry of Mesoporous NiO Electrodes in Iodide/Triiodide Electrolytes. J. Phys. Chem. C 2007, 111, 17455-17458. [CrossRef]

11. Borgström, M.; Blart, E.; Boschloo, G.; Mukhtar, E.; Hagfeldt, A.; Hammarström, L.; Odobel, F. Sensitized Hole Injection of Phosphorus Porphyrin into NiO: Toward New Photovoltaic Devices. J. Phys. Chem. B 2005, 109, 22928-22934. [CrossRef] [PubMed]

12. Gibson, E.A.; Smeigh, A.L.; le Pleux, L.; Fortage, J.; Boschloo, G.; Blart, E.; Pellegrin, Y.; Odobel, F.; Hagfeldt, A.; Hammarström, L. A p-Type NiO-Based Dye-Sensitized Solar Cell with an Open-Circuit Voltage of 0.35 V. Angew. Chem. Int. Ed. 2009, 48, 4402-4405. [CrossRef] [PubMed]

13. Qin, P.; Zhu, H.; Edvinsson, T.; Boschloo, G.; Hagfeldt, A.; Sun, L. Design of an Organic Chromophore for P-Type Dye-Sensitized Solar Cells. J. Am. Chem. Soc. 2008, 130, 8570-8571. [CrossRef] [PubMed]

14. Abbotto, A.; Manfredi, N.; Marinzi, C.; de Angelis, F.; Mosconi, E.; Yum, J.H.; Zhang, X.X.; Nazeeruddin, M.K.; Gratzel, M. Di-branched di-anchoring organic dyes for dye-sensitized solar cells. Energy Environ. Sci. 2009, 2, 1094-1101. [CrossRef]

15. Abbotto, A.; Leandri, V.; Manfredi, N.; de Angelis, F.; Pastore, M.; Yum, J.H.; Nazeeruddin, M.K.; Gratzel, M. Bis-Donor-Bis-Acceptor Tribranched Organic Sensitizers for Dye-Sensitized Solar Cells. Eur. J. Org. Chem. 2011, 2011, 6195-6205. [CrossRef]

16. Manfredi, N.; Cecconi, B.; Abbotto, A. Multi-Branched Multi-Anchoring Metal-Free Dyes for Dye-Sensitized Solar Cells. Eur. J. Org. Chem. 2014, 2014, 7069-7086. [CrossRef]

17. Nattestad, A.; Mozer, A.J.; Fischer, M.K.R.; Cheng, Y.B.; Mishra, A.; Bauerle, P.; Bach, U. Highly efficient photocathodes for dye-sensitized tandem solar cells. Nat. Mater. 2010, 9, 31-35. [CrossRef] [PubMed]

18. Zhang, X.L.; Zhang, Z.; Chen, D.; Bauerle, P.; Bach, U.; Cheng, Y.-B. Sensitization of nickel oxide: Improved carrier lifetime and charge collection by tuning nanoscale crystallinity. Chem. Commun. 2012, 48, 9885-9887. [CrossRef] [PubMed]

19. Li, L.; Gibson, E.A.; Qin, P.; Boschloo, G.; Gorlov, M.; Hagfeldt, A.; Sun, L. Double-Layered NiO Photocathodes for $p$-Type DSSCs with Record IPCE. Adv. Mater. 2010, 22, 1759-1762. [CrossRef] [PubMed]

20. Qin, P.; Linder, M.; Brinck, T.; Boschloo, G.; Hagfeldt, A.; Sun, L. High Incident Photon-to-Current Conversion Efficiency of $p$-Type Dye-Sensitized Solar Cells Based on NiO and Organic Chromophores. Adv. Mater. 2009, 21, 2993-2996. [CrossRef]

21. Zhu, L.; Yang, H.B.; Zhong, C.; Li, C.M. Rational design of triphenylamine dyes for highly efficient $p$-type dye sensitized solar cells. Dyes Pigment. 2014, 105, 97-104. [CrossRef]

22. Yen, Y.-S.; Chen, W.-T.; Hsu, C.-Y.; Chou, H.-H.; Lin, J.T.; Yeh, M.-C.P. Arylamine-Based Dyes for $p$-Type Dye-Sensitized Solar Cells. Org. Lett. 2011, 13, 4930-4933. [CrossRef] [PubMed]

23. Melikian, G.; Rouessac, F.P.; Alexandre, C. Synthesis of Substituted Dicyanomethylendihydrofurans. Synth. Commun. 1995, 25, 3045-3051. [CrossRef]

24. Yassar, A.; Videlot, C.; Jaafari, A. Synthesis and photovoltaic properties of mono-substituted quaterthiophenes bearing strong electron-withdrawing group. Sol. Energy Mater. Sol. Cells 2006, 90, 916-922. [CrossRef]

25. Barrette, W.C.; Johnson, H.W.; Sawyer, D.T. Voltammetric evaluation of the effective acidities (pKa') for Broensted acids in aprotic solvents. Anal. Chem. 1984, 56, 1890-1898. [CrossRef] [PubMed]

26. Bockris, J.O.M.; Khan, S.U.M. Surface Electrochemistry-A Molecular Level Approach; Kluwer Academic/ Plenum Publishers: New York, NY, USA, 1993.

27. Scrascia, A.; Pastore, M.; Yin, L.; Anna Picca, R.; Manca, M.; Guo, Y.-C.; de Angelis, F.; Della Sala, F.; Cingolani, R.; Gigli, G.; et al. Organic Dyes Containing A Triple Bond Spacer for Dye Sensitized Solar Cells: A Combined Experimental and Theoretical Investigation. Curr. Org. Chem. 2011, 15, 3535-3543. [CrossRef]

28. Mba, M.; D’Acunzo, M.; Salice, P.; Carofiglio, T.; Maggini, M.; Caramori, S.; Campana, A.; Aliprandi, A.; Argazzi, R.; Carli, S.; et al. Sensitization of Nanocrystalline $\mathrm{TiO}_{2}$ with Multibranched Organic Dyes and Co(III)/(II) Mediators: Strategies to Improve Charge Collection Efficiency. J. Phys. Chem. C 2013, 117, 19885-19896. [CrossRef]

29. Ji, Z.Q.; Natu, G.; Huang, Z.J.; Wu, Y.Y. Linker effect in organic donor-acceptor dyes for $p$-type NiO dye sensitized solar cells. Energy Environ. Sci. 2011, 4, 2818-2821. [CrossRef] 
30. Barolo, C.; Nazeeruddin, M.K.; Fantacci, S.; Di Censo, D.; Comte, P.; Liska, P.; Viscardi, G.; Quagliotto, P.; de Angelis, F.; Ito, S.; et al. Synthesis, Characterization, and DFT-TDDFT Computational Study of a Ruthenium Complex Containing a Functionalized Tetradentate Ligand. Inorg. Chem. 2006, 45, 4642-4653. [CrossRef] [PubMed]

31. Qin, P.; Wiberg, J.; Gibson, E.A.; Linder, M.; Li, L.; Brinck, T.; Hagfeldt, A.; Albinsson, B.; Sun, L.C. Synthesis and Mechanistic Studies of Organic Chromophores with Different Energy Levels for $p$-Type Dye-Sensitized Solar Cells. J. Phys. Chem. C 2010, 114, 4738-4748. [CrossRef]

32. Petersson, G.A.; Nakatsuji, H.; Caricato, M.; Li, X.; Hratchian, H.P.; Izmaylov, A.F.; Bloino, J.; Zheng, G.; Sonnenberg, J.L.; Hada, M.; et al. Gaussian 09, revision A.02.; Gaussian, Inc.: Wallingford, CT, USA, 2009.

33. Autschbach, J. Charge-Transfer Excitations and Time-Dependent Density Functional Theory: Problems and Some Proposed Solutions. Chemphyschem 2009, 10, 1757-1760. [CrossRef] [PubMed]

34. Ziegler, T.; Seth, M.; Krykunov, M.; Autschbach, J.; Wang, F. Is charge transfer transitions really too difficult for standard density functionals or are they just a problem for time-dependent density functional theory based on a linear response approach. J. Mol. Struct. THEOCHEM 2009, 914, 106-109. [CrossRef]

35. Becke, A.D. Density-functional thermochemistry. III. The role of exact exchange. J. Chem. Phys. 1993, 98, 5648-5652. [CrossRef]

36. Becke, A.D. A new mixing of Hartree-Fock and local density-functional theories. J. Chem. Phys. 1993, 98, 1372-1377. [CrossRef]

37. Koch, W.; Holthausen, M. A Chemist's Guide to Density Functional Theory, 2nd ed.; Wiley-VCH: Weinheim, Germany, 2001.

38. Gregg, B.A. Excitonic Solar Cells. J. Phys. Chem. B 2003, 107, 4688-4698. [CrossRef]

39. Zhen, C.-G.; Becker, U.; Kieffer, J. Tuning Electronic Properties of Functionalized Polyhedral Oligomeric Silsesquioxanes: A DFT and TDDFT Study. J. Phys. Chem. A 2009, 113, 9707-9714. [CrossRef] [PubMed]

40. Kim, B.-G.; Zhen, C.-G.; Jeong, E.J.; Kieffer, J.; Kim, J. Organic Dye Design Tools for Efficient Photocurrent Generation in Dye-Sensitized Solar Cells: Exciton Binding Energy and Electron Acceptors. Adv. Funct. Mater. 2012, 22, 1606-1612. [CrossRef]

41. Choi, H.; Baik, C.; Kang, S.O.; Ko, J.; Kang, M.-S.; Nazeeruddin, M.K.; Grätzel, M. Highly Efficient and Thermally Stable Organic Sensitizers for Solvent-Free Dye-Sensitized Solar Cells. Angew. Chem. Int. Ed. 2008, 47, 327-330. [CrossRef] [PubMed]

42. Bisquert, J.; Fabregat Santiago, F. Impedance spectroscopy: A general introduction and application to dye-sensitized solar cells. In Dye Sensitized Solar Cells; Kalyanasundaram, K., Ed.; CRC Press: Boca Raton, FL, USA, 2010.

43. Bisquert, J. Chemical capacitance of nanostructured semiconductors: Its origin and significance for nanocomposite solar cells. Phys. Chem. Chem. Phys. 2003, 5, 5360-5364. [CrossRef]

44. Lefebvre, J.F.; Sun, X.Z.; Calladine, J.A.; George, M.W.; Gibson, E.A. Promoting charge-separation in $p$-type dye-sensitized solar cells using bodipy. Chem. Commun. 2014, 50, 5258-5260. [CrossRef] [PubMed]

45. Yang, Z.; Zhao, N.; Sun, Y.; Miao, F.; Liu, Y.; Liu, X.; Zhang, Y.; Ai, W.; Song, G.; Shen, X.; et al. Highly selective red- and green-emitting two-photon fluorescent probes for cysteine detection and their bio-imaging in living cells. Chem. Commun. 2012, 48, 3442-3444. [CrossRef] [PubMed]

46. Lee, D.H.; Lee, M.J.; Song, H.M.; Song, B.J.; Seo, K.D.; Pastore, M.; Anselmi, C.; Fantacci, S.; de Angelis, F.; Nazeeruddin, M.K.; et al. Organic dyes incorporating low-band-gap chromophores based on $\pi$-extended benzothiadiazole for dye-sensitized solar cells. Dyes Pigments 2011, 91, 192-198. [CrossRef]

47. O’Boyle, N.M.; Tenderholt, A.L.; Langner, K.M. cclib: A library for package-independent computational chemistry algorithms. J. Comput. Chem. 2008, 29, 839-845. [CrossRef] [PubMed]

(c) 2016 by the authors; licensee MDPI, Basel, Switzerland. This article is an open access article distributed under the terms and conditions of the Creative Commons by Attribution (CC-BY) license (http:/ / creativecommons.org/licenses/by/4.0/). 